\title{
FGF19 Gene Amplification
}

National Cancer Institute

\section{Source}

National Cancer Institute. FGF19 Gene Amplification. NCI Thesaurus. Code C150612.

A molecular genetic abnormality indicating the presence of multiple copies of the FGF19 gene. 